\title{
A Durkheimian Analysis of Racialised Crime and Punishment Police Practices and the Demand for Change
}

\author{
Anna Kovar \\ MSc in Criminology and Criminal Justice, University of Edinburgh
}

\begin{abstract}
The analysis of racialised police attitudes has been frequently addressed in academic articles, but the application of a Neo-Durkheimian approach has been largely overlooked. This article will apply Durkheimian theory to illuminate the need for a shift in crime and punishment policy and practices to avoid the present societal moral stagnation. In order to do so it will address both, the recent Black Lives Matter protests in America and the 2011 Riots in London. The use of the two case studies signifies the continuity of problematic police behaviour and political address. It is evident that such an article is embedded in an extremely sensitive topic, therefore it does not presume to provide a solution to the overwhelming circumstances. Rather, in illuminating the relevance of Durkheimian theory it signifies that current global circumstances demand a moral shift in societal understandings of solidarity and "the cult of the individual", providing pivotal foundations for police practices. However, this requires participation of criminologists alongside practitioners and activists.
\end{abstract}

Keywords: Durkheim, cult of the individual, racialised policing, Black Lives Matter, 2011 Tottenham Riots 


\section{Introduction}

Durkheim is considered to be a "founding father" of sociology. ${ }^{1}$ It has been over a century since his passing, but his importance remains steadfast. ${ }^{2}$ However, "Durkheim is in need of redemption and recognition" ${ }^{3}$ in the field of criminology. Durkheim's ideas are still of relevance today, as they equip researchers with tools to challenge institutions and reflect on society's values and inequalities. This essay applies Durkheim's concepts to crime, punishment, and responses to the context of the 2011 riots in Tottenham, London, and the recent global Black Lives Matter (BLM) protests.

This paper does not presume to provide an all-encompassing interpretation of Durkheim's ideas. For example, this essay does not discuss his work on suicide, ${ }^{4}$ nor does it perform an evaluation of his penal evolution. ${ }^{5}$ While these related bodies of works are mentioned, they are not the central focus. Rather, this essay argues that Durkheim's radical notion of critiquing social structures ${ }^{6}$ is central to the future of crime and punishment theory today. By contextualising Durkheim's concepts to align with contemporary crises, his concern for inequalities ${ }^{7}$ will be expanded to include the consideration of race.

Throughout this paper, Durkheim's ideas on solidarity, anomie, collective effervescence, and the "cult of the individual"8 will be applied to interpret the chosen events. Durkheim believed that observing reality induces morality. ${ }^{9}$ The resulting morality in turn exposes the crime and punishment rationales of society, thereby signifying the values and inequalities upheld by society. The police, as central figures in crime control and punishment, embody such values and inequalities. This essay reveals that Durkheim's ideas are of value in exposing

\footnotetext{
${ }^{1}$ Liza Herzog, "Durkheim on Social Justice: The Argument from 'Organic Solidarity'," American Political Science Review 112, no.1 (2018): 112.

${ }^{2}$ Robert Bierstedt, Emile Durkheim (London: Weidenfeld and Nicolson, 1966), 29.

${ }^{3}$ Shadd Maruna, "Reentry as a Rite of Passage," Punishment and Society 13 no. 1, (2011): 6.

${ }^{4}$ Ken Morrison, Marx, Durkheim, Weber (London: SAGE Publications Ltd, 1998).

${ }^{5}$ Steven Lukes, Emile Durkheim: His Life and Work: A Historical and Critical Study (Middlesex: Penguin Books Ltd, 1973), 159.

${ }^{6}$ Jennifer Lehmann, “The Question of Caste in Modern Society: Durkheim's Contradictory Theories of Race, Class and Sex,” American Sociological Review 60, no. 4 (1995): 583.

${ }^{7}$ Anthony Giddens, Emile Durkheim: Selected Writings (Cambridge: Cambridge University Press, 1972), 12.

${ }^{8}$ Giddens, Emile Durkheim, 22.

${ }^{9}$ Giddens, 95.
} 
inequalities and threats to solidarity, but if Durkheim is to be of any practical influence, a shift to avoid moral stagnation beginning with the police must be enforced.

This essay begins by discussing Durkheim's aforementioned ideas. It is then split into four sections, focusing on the Durkheimian police, the 2011 Tottenham riots, Black Lives Matter, and, finally, the demand for a shift. It continuously implements Durkheim's ideas to reveal the role of the police in conveying societal values and inequalities, whilst simultaneously portraying the evident need for an evolutionary transition ${ }^{10}$ in moral solidarity.

\section{Durkheim and His Concepts}

David Émile Durkheim was born in the Lorraine region of France in $1858 .{ }^{11}$ His childhood experience of war and Jewish upbringing led him to believe that social science could be a source for national unity. ${ }^{12}$ Durkheim's major works include The Division of Labor in Society (1893), The Rules of Sociological Method (1895), Suicide (1897), and The Elementary Forms of Religious Life (1912). All are contextually rooted in the political climate of France and the unprecedented threat to group life at the time. ${ }^{13}$ Durkheim saw a need for a revival, ${ }^{14}$ with an attempt to balance individualism and socialism. ${ }^{15}$ The emergence of an industrial society led to his idea of stratification ${ }^{16}$ as an aim to address the advanced division of labour. His desire was to seek unity amongst the turmoil of modernity. ${ }^{17}$ Durkheim's concern with individual freedom and social order ${ }^{18}$ made the sociologist a moralist. ${ }^{19}$

In The Division of Labor, Durkheim focused on solidarity during the rapid social and economic transition of modernity. For him, industrialisation was not the end of solidarity, but

\footnotetext{
${ }^{10}$ Kenneth Thompson, Emile Durkheim (Chichester: Ellis Horwood Ltd., 1982), 68.

${ }^{11}$ Lukes, Emile Durkheim, 29.

12 Thompson, Emile Durkheim, 12.

${ }^{13}$ Morrison, Marx, Durkheim, Weber, 121.

${ }^{14}$ Lukes, Emile Durkheim, 42.

${ }^{15}$ Roger Cotterrell, Emile Durkheim: Law in a Moral Domain (Edinburgh: Edinburgh University Press, 1999), 24.

${ }^{16}$ Jean-Claude Filloux, "Inequalities and Social Stratification in Durkheim's Sociology,” in Emile Durkheim: Sociologist and Moralist, ed. Stephen Turner (London: Taylor and Francis Group, 1993), 205.

${ }^{17}$ Elgin Mannion, “Autonomy, Race and State Reproduction of Status: Durkheim and Weber on Education and Immigration," Critical Sociology 42, no. 4-5 (2016): 701.

18 Thompson, Emile Durkheim, 71.

${ }^{19}$ Michèle Richman, Sacred Revolutions: Durkheim and the Collège de Sociologie (Minnesota: University of Minnesota Press, 2002), 62.
} 
instead demanded a reconfiguration of its origin. ${ }^{20}$ In his work, Durkheim expressed two evolutionary stages of solidarity: "mechanical solidarity," which can be found in unified societies and is based on the notion of sameness, ${ }^{21}$ and "organic solidarity," consisting of a high level of differentiation. ${ }^{22} \mathrm{He}$ noted that dependency is present in organic solidarity, as "cooperation between individuals or groups of individuals" becomes essential. ${ }^{23}$

In stark contrast to solidarity, Durkheim proposed anomie. Anomie is a fluid concept with a long history of various uses. This essay refers to the anomie described in The Division of Labor, as opposed to the homo duplex form found in Suicide. ${ }^{24}$ Anomie is the condition produced by the forced division of labour, a lack of regulation, inequalities, or unjust exchange rates in worth. ${ }^{25}$ I specifically refer to anomie produced by inequalities in this essay. This form of anomie occurs if there are external inequalities ${ }^{26}-$ that is, an unequal distribution of material factors hindering an individual's opportunities. ${ }^{27}$ Durkheim focused on the external inequality present in inherited economic disparity and believed that solidarity demanded its abolition. ${ }^{28}$ He also described the internal inequality of aptitude. ${ }^{29}$ Referring to his concepts of solidarity, he maintained that organic solidarity could be assisted with the elimination of social inequalities, thereby avoiding anomie. ${ }^{30}$

In The Elementary Forms of Religious Life, Durkheim explained religion's role within society. He perceived it as the moral and cognitive basis of social solidarity, providing the base from which "various manifestations of collective life have occurred." ${ }^{11}$ In 1882, a Primary Education law promoted free compulsory non-religious education for all children in France. In response, Durkheim felt responsible for finding a place for morality without familiar

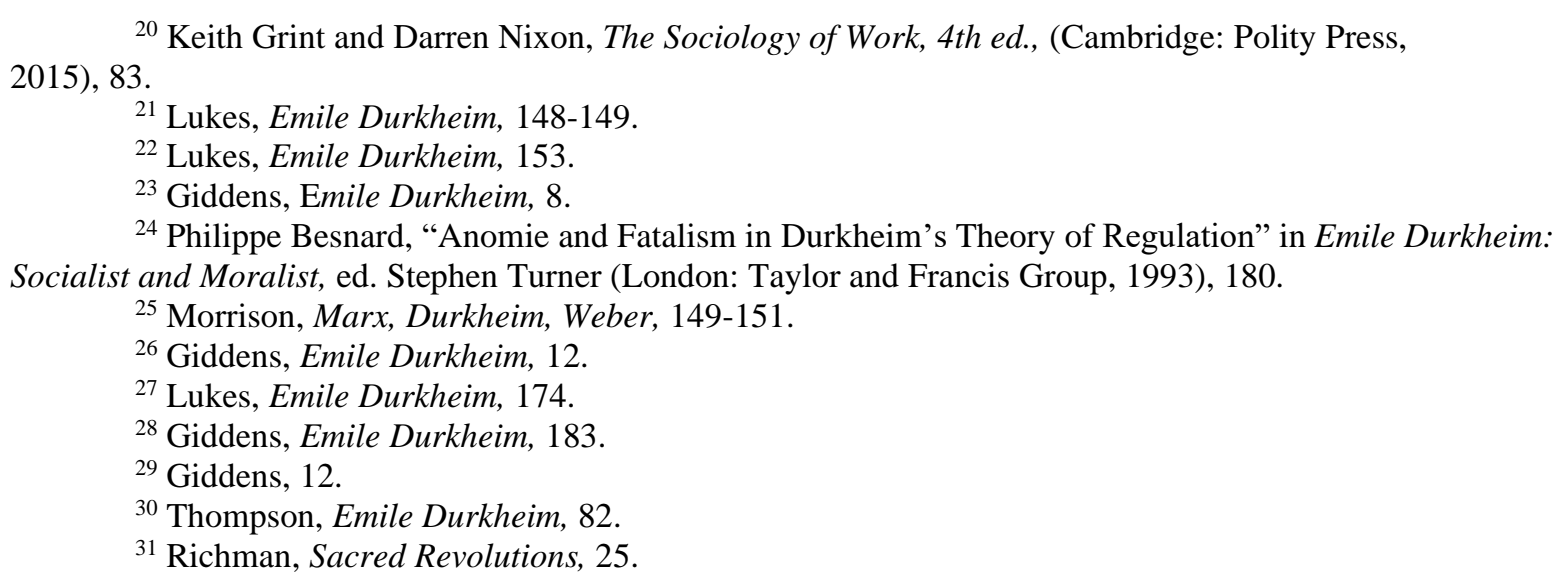

${ }^{20}$ Keith Grint and Darren Nixon, The Sociology of Work, 4th ed., (Cambridge: Polity Press,

${ }^{21}$ Lukes, Emile Durkheim, 148-149.

${ }^{22}$ Lukes, Emile Durkheim, 153.

${ }^{23}$ Giddens, Emile Durkheim, 8.

${ }^{24}$ Philippe Besnard, “Anomie and Fatalism in Durkheim's Theory of Regulation" in Emile Durkheim: Socialist and Moralist, ed. Stephen Turner (London: Taylor and Francis Group, 1993), 180.

${ }^{25}$ Morrison, Marx, Durkheim, Weber, 149-151.

${ }^{26}$ Giddens, Emile Durkheim, 12.

${ }^{27}$ Lukes, Emile Durkheim, 174.

${ }^{28}$ Giddens, Emile Durkheim, 183.

${ }^{29}$ Giddens, 12.

30 Thompson, Emile Durkheim, 82.

${ }^{31}$ Richman, Sacred Revolutions, 25. 
religiosity.$^{32} \mathrm{He}$ was critiqued for presenting a "dogmatic secular religion" contradicting the spiritual revival some longed for. ${ }^{33}$ To Durkheim, religion was functional, conveying morality through group affirmation. ${ }^{34} \mathrm{He}$ studied Aboriginal societies in Australia to comprehend their notion of totemism and how symbolisation created the sacred which regulated relations. ${ }^{35} \mathrm{He}$ defined religion as "a system of collective beliefs and practices that have a special authority," 36 arguing that religion derived from collective representations that expressed collective realities ${ }^{37}$ - in other words, all that is social is religious. ${ }^{38}$ To Durkheim, the sacred is produced through rituals that establish social bonds. ${ }^{39}$ These bonds become sacred aims that provide the "ends of morality, ${ }^{40}$ tying morality to the ideal end of action. ${ }^{41}$ Durkheim saw the sacred as nothing more "than society hypostasized and transfigured." ${ }^{42}$ Therefore, to him, the divine is society. ${ }^{43}$

In his article Individualism and the Intellectuals (1898), Durkheim took this interpretation of religion to produce a religion of "today." The most "beloved thing" in modern societies, he argued, is "man himself." 44 "A religion of humanity is the religion of today." 45 This he named the "cult of the individual." ${ }^{46}$ It is neither instinctive egoism, nor Spencer's egotistic economics, ${ }^{47}$ but rather the sacrality of the individual. ${ }^{48}$ To Durkheim, the co-dependency of solidarity occurs through placing the individual over the self. ${ }^{49}$ Meanwhile, the collective conscience is the "set of beliefs and sentiments common to the average member of a single

${ }^{32}$ Cotterrell, Emile Durkheim, 25.

${ }^{33}$ Richman, Sacred Revolutions, 24.

${ }^{34}$ Lukes, Emile Durkheim, 475.

35 Thompson, Emile Durkheim, 133.

${ }^{36}$ Stephen Lukes, "Durkheim's Individualism and the Intellectuals," Political Studies 17, no.1, (Oxford: Oxford University Press, 1969), 25.

${ }^{37}$ Thompson, Emile Durkheim, 125.

${ }^{38}$ Lukes, Emile Durkheim, 152.

39 Thompson, Emile Durkheim, 32.

${ }^{40}$ Raquel Weiss, "From Ideas to Ideals: Effervescence as the Key to Understanding Morality," Durkheim Studies, 18 (2012): 86.

${ }^{41}$ Ernest Wallwork, Durkheim: Morality and Milieu (Cambridge: Harvard University Press, 1972), 48

${ }^{42}$ Emile Durkheim, The Elementary Forms of Religious Life: A Study in Religious Sociology, trans. Joseph Swain, (London: Allen and Unwin, 1915), 347.

${ }^{43}$ Emile Durkheim, Sociology and Philosophy, trans. David F. Pocock (London: Cohen and West, 1953), 52.

${ }^{44}$ Lukes, "Durkheim's Individualism”, 26.

${ }^{45}$ Giddens, Emile Durkheim, 23.

${ }^{46}$ Giddens, 22.

${ }^{47}$ Lukes, “Durkheim's Individualism”, 20.

${ }^{48}$ Giddens, Emile Durkheim, 22.

49 Thompson, Emile Durkheim, 65. 
society which forms a determinate system that has its own life." ${ }^{50}$ The collective mind therefore structures society; ${ }^{51}$ it forms the moral framework ${ }^{52}$ and the religion of society. ${ }^{53}$ For Durkheim, the collective is external to the individual, transmitted from the whole holding a special energy: effervescence. ${ }^{54}$ Durkheim was not concerned with the psychological studies of the crowd but the functional outcomes of collective effervescence. ${ }^{55} \mathrm{He}$ argued that effervescence is a window to the sacred and is consequentially important to understanding morality. ${ }^{56}$

A crime "offends [...] the collective conscience." ${ }^{57}$ Since, according to Durkheim, the collective conscience represents shared beliefs, ${ }^{58}$ which in modernity is the cult of the individual, an act against the individual is the most expressive form of a crime. However, Durkheim explained that a certain level of crime is normal, ${ }^{59}$ allowing a society to reaffirm itself through criminal punishment. ${ }^{60} \mathrm{He}$ believed that crime could represent the morality of the future $^{61}$ if it transforms social beliefs. Therefore, from a Durkheimian perspective, punishment and crime control practices must symbolise and align with the cult of the individual if it intends to maintain solidarity within modernity.

\section{Durkheimian Police}

The representation of the collective conscience comes in the form of the state. However, the state does not encompass the entirety of the collective conscience. Rather, it represents the "most vivid" elements. ${ }^{62}$ Organic solidarity is reliant on the state's regulation of corporations to ensure individual dignity. ${ }^{63}$ Nevertheless, the core values of a society are not executed by

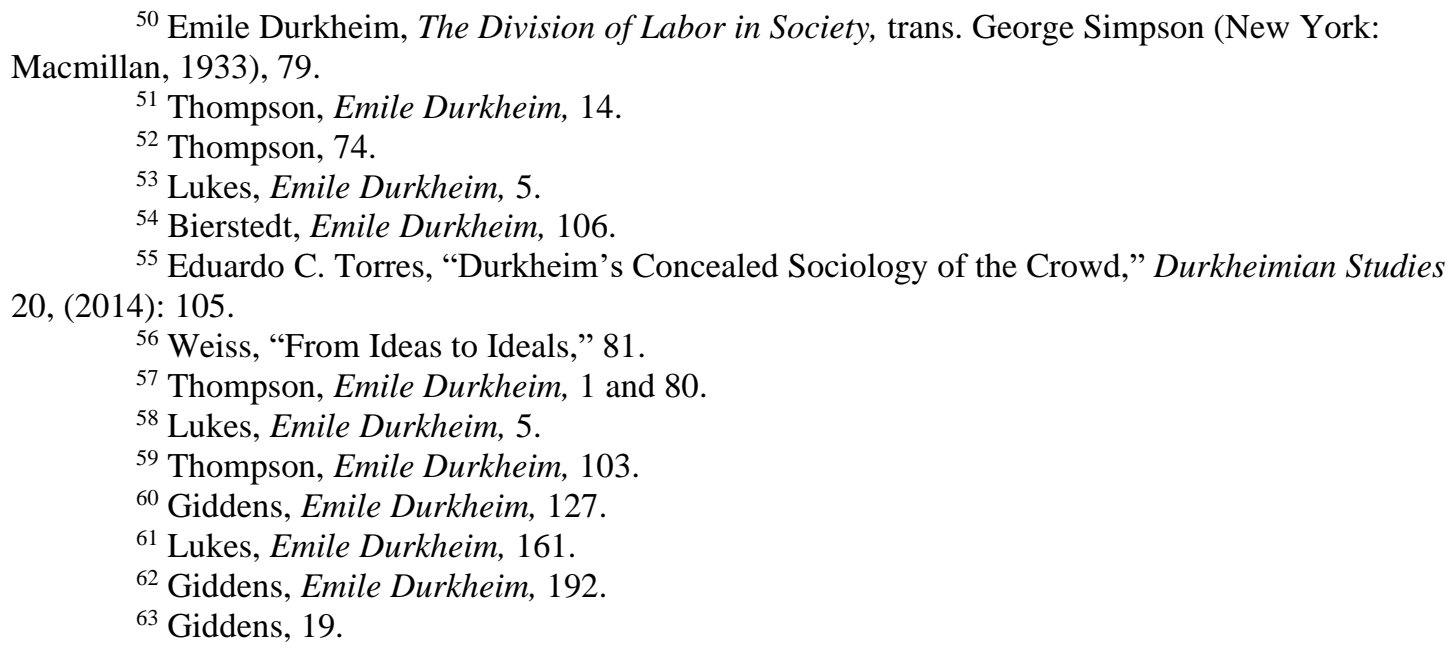


the state but through secondary agencies. ${ }^{64}$ These agencies are the "channels of communication" that enable continuous integration between people and the state. ${ }^{65}$ Durkheim's desire to avoid a socialist authoritarian government or a polarised democracy ${ }^{66}$ led to other channels of communication being required ${ }^{67}$ To Durkheim, the communicative channels and the state are the directive through which collective life is symbolised. ${ }^{68}$ The police are a regulative organ that communicates between the government and the masses, establishing them as one of these secondary agencies. ${ }^{69}$ The police represent the moral architecture of the community ${ }^{70}$ constructing and reconstructing moral and social order..$^{71}$ Their actions are thus "socially generated and about society," 72 expressing collective realities. ${ }^{73}$ They must therefore be dignified, aligned, and fair, revolving around social cohesion ${ }^{74}$ and the individual's sacredness. ${ }^{75}$

The police enact the most visible everyday forms of criminal punishment, which is a public ritual to restore social order by responding to a threat to the collective. ${ }^{76}$ Durkheim considered the law to be the core morals, ${ }^{77}$ which can cool popular convictions,${ }^{78}$ it is enacted to ensure cohesion in a specific context, ${ }^{79}$ representing the common requirements of social well-being. ${ }^{80}$ In societies with organic solidarity, the final morality is the "sacredness of man, human rights and international solidarity." 81 Therefore, moral action must not degrade the individual. ${ }^{82}$ The

${ }^{64}$ Lukes, Emile Durkheim, 269.

${ }^{65}$ Giddens, Emile Durkheim, 19.

${ }^{66}$ Cotterrell, Emile Durkheim, 163.

${ }^{67}$ Wallwork, Durkheim, 107.

${ }^{68}$ Bierstedt, Emile Durkheim, 62.

${ }^{69}$ Bruce DiCristina, "Durkheim's Theory of Anomie and Crime: A Clarification and Elaboration," Australia and New Zealand Journal of Criminology 49, no. 3 (2016): 317.

${ }^{70}$ Jonathan Jackson and Jason Sunshine, "Public Confidence in Policing: A Neo-Durkheimian

Perspective," The British Journal of Criminology 47, no. 2 (2007): 215.

${ }^{71}$ Jackson and Sunshine, "Public Confidence," 220.

${ }^{72}$ Lukes, Emile Durkheim, 7.

${ }^{73}$ Morrison, Marx, Durkheim, Weber, 154.

${ }^{74}$ Jackson and Sunshine, "Public Confidence," 214.

${ }^{75}$ Lukes, Emile Durkheim, 518.

${ }^{76}$ Maruna, "Reentry as a Rite", 6.

${ }^{77}$ Cotterrell, Emile Durkheim, 50.

${ }^{78}$ Cotterrell, Emile Durkheim, 190.

${ }^{79}$ Roger Cotterrell, “Justice, Dignity, Torture, Headscarves: Can Durkheim's Sociology

Clarify Legal Values," Social and Legal Studies 20, no. 1 (2011): 6-7.

${ }^{80}$ Cotterrell, Emile Durkheim, 72.

${ }^{81}$ Wallwork, Durkheim, 191.

${ }^{82}$ Giddens, Emile Durkheim, 178. 
collective effervescence provides an emotional exterior to the individual, thus maintaining harmony and solidarity. ${ }^{83}$ Since punishment is an "expressive institution," 84 the cult of the individual requires the reduction of punishment that offends individual dignity. ${ }^{85}$ The need to reject such actions indicates that penal practices hold social meaning. ${ }^{86}$

A neo-Durkheimian task is to consider when "punishment becomes dysfunctional" those which hinder solidarity. The communicative power of punishment to disrupt solidarity is unparalleled. ${ }^{88}$ Varying penal practices may have different cultural meanings. For example, to conservative Americans, the death penalty is seen as an underused tool, whilst for "African Americans, it communicates the message of unacceptable racial violence and lynching." ${ }^{\circ 9}$ Any change in penal culture necessarily reflects a change in social relations. ${ }^{90}$ Where actions that contravene beliefs occur, the masses must be consulted in order to evaluate how crime and punishment is practiced, particularly in cases of violent and racist behaviour on the part of the police. In recognising the communicative power of punishment and the police's representation of the core values of society, questions concerning whose solidarity is being formed must be asked when considering dysfunctional punishment - just as Burkhardt and Connor ask when critiquing the privatisation of prisons. ${ }^{91}$

In the two letters he wrote in response to the Dreyfus Affair,,${ }^{92}$ Durkheim argued that there is no reason for a state to place outrage against one person. ${ }^{93}$ If solidarity is based on the value

\footnotetext{
${ }^{83}$ Wallwork, Durkheim, 27.

${ }^{84}$ David Garland, "Frameworks of Inquiry in the Sociology of Punishment," The British Journal of Sociology 41, no. 1 (1990): 8.

${ }^{85}$ Cotterrell, Emile Durkheim, 79.

${ }^{86}$ David Garland, "Concepts of Culture in the Sociology of Punishment," Theoretical Criminology 10, no. 4 (2006): 428.

${ }^{87}$ Brett C. Burkhardt and Brian T. Connor, "Durkheim, Punishment and Prison Privatization," Social Currents 3, no. 1 (2016): 86.

${ }^{88}$ Burkhardt and Connor, "Durkheim," 93.

${ }^{89}$ Garland, "Concepts of Culture," 435.

${ }^{90}$ Garland, 434.

${ }^{91}$ Burkhardt and Connor, "Durkheim," 84-85.

92 In the $18^{\text {th }}$ century Alfred Dreyfus, a Jewish artillery officer, was falsely convicted of passing military secrets to the enemy Germans and sentenced to death on Devil's Island. It created society wide antiSemitic attitudes that contradicted the inclusive motif of the French emancipation. The trial turned into an international affair due to evidence proving Dreyfus' innocence leading to politically and ideologically infused riots. Dreyfus was returned to France in 1899 to be re-trialed. He was once again sentenced guilty, but the President of France pardoned him. In 1906 Dreyfus was acquitted.

${ }^{93}$ Lukes, “Durkheim's Individualism," 14.
} 
of the individual, an attempt on a man's life will produce "horror as though in touch with the profane. ${ }^{" 94}$ Homicide should thus decrease. ${ }^{95}$ Yet the killing of Black men by the police in America and the UK is "institutionalised behaviour." 96 These racist killings by the police suggest a continuation of punishment that disregards the dignity of the individual. If beliefs and values are crystallised in institutions that sanction, the police perform as a cult of the individual that excludes Black individuals. A segmentary society is one in which the laws protect the elite, making it repressive. ${ }^{97}$ Messner et al. argue that if solidarity is hierarchical, it is criminogenic. ${ }^{98}$ The law which excludes Blackness from sacredness is therefore criminogenic.

The criminalisation of Black individuals - by the police, ${ }^{99}$ the prison system, ${ }^{100}$ and the media $^{101}$ - is evident. Tamir Rice's death in 2014 conveyed the extent of this criminalisation, which robs Black children of their childhood. ${ }^{102}$ White supremacy has normalised Black criminality, creating a "new morality." 103 There is a connection between these moral values and the "production of racism." 104 Is it not central for the production of non-criminogenic solidarity that Black individuals are sacralised so moral norms repel racism. However, Maruna explains that rituals of re-entry (societal recognition of belonging or, in Durkheimian terms, sacredness) can be undermined by subsequent degradation. ${ }^{105}$ The killing of Black individuals by the police is symbolic of the repeated undermining of sacred Blackness. The law that protects white supremacy is disguised by "post-race institutions," making race "invisible to those [who are]

\footnotetext{
${ }^{94}$ Lukes, 22.

${ }^{95}$ Steven F. Messner et al., "Institutions, Anomie and Violent Crime: Clarifying and Elaborating Institutional-Anomie Theory," International Journal of Conflict and Violence 2, no. 2 (2008): 170.

${ }^{96}$ Messner et al., "Institutions, Anomie and Violent Crime," 166.

${ }^{97}$ Fergus McNeill and Matt Dawson, "Social Solidarity, Penal Evolution and Probation," The British Journal of Criminology 54, no. 5 (2014): 895.

${ }^{98}$ Messner et al., "Institutions, Anomie and Violent Crime," 170.

${ }^{99}$ Lisa J. Long, Perpetual Suspects (London: Palgrave Studies, 2018), 177.

${ }^{100}$ Katheryn Russell-Brown, "Critical Black Protectionism, Black Lives Matter, and Social

Media: Building a Bridge to Social Justice,” Howard Law Journal, 60 (2017): 382.

${ }^{101}$ Stuart Hall, Policing the Crisis: Mugging, the State and Law and Order (New York:

Macmillan Publishers, 1978); Russell-Brown, "Critical Black Protectionism," 380.

${ }^{102}$ Stacey J. Lee et al., "Asians for Black Lives, Not Asians for Asians: Building Southeast

Asian American and Black Solidarity," Anthropology and Education 51, no. 4 (2020): 413.

103 Weiss, "From Ideas to Ideals," 89.

${ }^{104}$ Long, Perpetual Suspects, 196.

${ }^{105}$ Maruna, "Reentry as a Rite," 17.
} 
privileged." 106 Therefore, the solidarity and morality of society represented by the police is one of exclusion, as evidenced in the lack of Black individuals seeking police help. ${ }^{107}$ The repeated use of institutions to control Black individuals ${ }^{108}$ or citizenship to protect white power from an imperial history ${ }^{109}$ is inextricably linked to the exclusion of Black individuals from the cult of the individual. The actions of the police confirm the racialised reality in which Black lives are devalued. ${ }^{110}$

The need to shift away from the criminogenic solidarity requires a new morality and sacralised individual implemented by the police. This morality, prior to its crystallisation, is brought about through "socially sanctioning actions," 111 such as protests and riots.

\section{The 2011 Tottenham Riots}

Durkheim's critique of inequalities and institutions has been deemed "radical." 112 Durkheim believed social equality upheld solidarity. ${ }^{113}$ While his contemporary, W.E.B. Du Bois, saw "the colour line" 114 as a crucial inequality, Durkheim failed to recognise the prominence of race. ${ }^{115}$ In a neo-Durkheimian approach to inequalities, race is included, making Durkheim's separation of internal and external inequalities paradoxical. ${ }^{116}$ Race significantly impacts material inequalities and one's aptitude, as aptitude may have derived from the external inequalities inherited over generations. This essay places race in Durkheim's concerns for equality. The criminalisation of Black people needs to be critiqued in order to remove inequalities. The following discussions of the chosen contemporary events enables the application of Durkheimian concepts in the context of racial inequalities.

\footnotetext{
${ }^{106}$ Long, Perpetual Suspects, 196.

${ }^{107}$ Long, Perpetual Suspects, 214.

${ }^{108}$ Loic Wacquant, "From Slavery to Mass Incarceration," New Left Review 1, (2002): 41.

${ }^{109}$ Long, Perpetual Suspects, 206.

${ }^{110}$ Meredith D. Clark, “White Folks' Work: Digital Allyship Praxis in the \#BlackLivesMatter
} Movement," Social Movement Studies 18, no. 5 (2019): 526.

${ }^{111}$ Richman, Sacred Revolutions, 59.

${ }^{112}$ Lehmann, "The Question of Caste", 583.

113 Thompson, Emile Durkheim, 82.

${ }^{114}$ Nisha Kapoor and Kasia Narkowicz, "Characterising Citizenship: Race, Criminalisation and the Extension of Internal Borders," Sociology 53, no. 4 (2019): 656; Walter R. Allen and Angie Chung "Your Blues Ain't Like My Blues: Race Ethnicity and Social Inequality in America," Contemporary Sociology 29, no. 6 (2000): 797.

115 David Roediger, "Making Solidarity Uneasy: Cautions on a Keyword from BLM to the Past," The American Studies Association 68, no. 2 (2016): 233.

${ }^{116}$ Filloux, "Inequalities and Social Stratification," 210. 
It must be noted that this analysis of the application of Durkheim's concepts to the selected events does not provide any solutions. It does, however, use Durkheim's work to refract light onto the policing surrounding these circumstances, thereby illuminating the morality and beliefs upheld by the relevant society. It also provides an opportunity to consider alternative approaches to crime and punishment in order to secure solidarity and avoid anomie through responding to the collective conscience.

On the 4th of August 2011, Mark Duggan, a Black British man, was shot dead by police in Tottenham. ${ }^{117}$ The media initially vilified Duggan, ${ }^{118}$ suggesting that he shot first, ${ }^{119}$ thereby attempting to legitimise the killing. This in turn spawned heavily documented riots, mass looting, and arson, lasting six days. ${ }^{120}$ Tottenham's Black community saw Duggan's death as a violation of the collective individual. ${ }^{121}$ Durkheim presents four forms of rites within the sacralisation process that demand action. ${ }^{122}$ The "piacular" rite is of relevance here. Piacular rites occur "when a society goes through circumstances which sadden, perplex or irritate it"123 and takes the form of public mourning to reclaim unity. ${ }^{124}$ The piacular rite both mobilises and passes on beliefs. ${ }^{125}$ The initial response to Duggan's death was a piacular protest demanding respect for all. Duggan's death and the ritualised march became what Waddington calls a "flashpoint" event, as it was counteracted with intensified policing that exaggerated negative police-community relations. ${ }^{126}$ The police's response of criminalising Duggan, alongside increased control and punishment distribution, indicated a segmentary society. It also reaffirmed the devaluing of Black individuals seen in the "disproportional representation [of

${ }^{117}$ Adam Elliot-Cooper, “The Struggle That Cannot Be Named: Violence, Space and The Rearticulation of Anti-racism in Post-Duggan Britain," Ethnic and Racial Studies 41, no. 14 (2018): 2446.

${ }^{118}$ Lynette Goddard, "BlackLivesMatter: Remembering Mark Duggan and David Oluwale in Contemporary British Plays," Journal of Contemporary Drama in English 6, no. 1 (2018): 76.

${ }^{119}$ Elliot-Cooper, "The Struggle That Cannot Be Named," 2445.

${ }^{120}$ Aaron Reeves and Robert deVries, "Does Media Coverage Influence Public Attitudes Towards Welfare Recipients? The Impact of the 2011 English Riots," The British Journal of Sociology 67, no. 2 (2016): 282.

${ }^{121}$ Herzog, "Durkheim on Social Justice", 117.

${ }^{122}$ Morrison, Marx, Durkheim, Weber, 205.

${ }^{123}$ Morrison, 211.

${ }^{124}$ Morrison, 211.

${ }^{125}$ Giddens, Emile Durkheim, 220.

${ }^{126}$ David Waddington, "The Law of Moments: Understanding the Flashpoint That Ignited the Riots," Criminal Justice Matters 87, no. 1 (2012): 6. 
Black individuals] in the criminal justice system." ${ }^{127}$ This event is indicative of a hierarchical society that protects white supremacy.

Since the 1980s, Tottenham has been a site of Black struggle. ${ }^{128}$ The death of Duggan produced a collective memory of the 1985 Broadwater Farm Riots. ${ }^{129}$ Riots had since become cultural heritage. ${ }^{130}$ Although in 2011 many rioters' justifications were based on anger toward the police, ${ }^{131}$ it was not always at the forefront of their minds. ${ }^{132}$ Other frustrations interlinked, such as unemployment and welfare cuts. ${ }^{133}$ In applying a Durkheimian interpretive approach, these riots can be understood as a crisis in modernity's evolution. The anomie produced through inequalities resulted in a "loss of direction, a sense of apathy, an absence of attachment to life itself." ${ }^{134}$ The looting was described as a spontaneous unity, ${ }^{135}$ correlating to the power of collective effervescence and its ability to produce sentiments one could not achieve alone. ${ }^{136}$ Crowds and mass gatherings produce "intense passion" 137 and the killing of Mark Duggan offended solidarity because it disregarded the sacrality of the individual. The law embodied by the police is supposed to cool popular emotion, ${ }^{138}$ but their response amplified passion. If there is "no respect for those producing legislations," then cooperation will stop and "collective solidarity will collapse."139

Cohen coined the term "moral panics," which emerge out of a threat to societal values stylised by the mass media. ${ }^{140}$ It is a form of collective effervescence in response to a crime. ${ }^{141}$ The media shapes societal values. Just as the mass media mobilised the crowds during the

\footnotetext{
${ }^{127}$ Katheryn Russell-Brown, "Critical Black Protectionism," 382.

128 Elliot-Cooper, "The Struggle That Cannot Be Named," 2445.

${ }^{129}$ Goddard, "BlackLivesMatter," 76.

${ }^{130}$ Tim Newburn et al, "The Biggest Gang? Police and People in the 2011 England Riots,"
} Policing and Society 28, no. 2 (2018): 213.

${ }^{131}$ Newburn et al., "The Biggest Gang?”, 210.

${ }^{132}$ Newburn et al., 207.

${ }^{133}$ Newburn et al., 214.

${ }^{134}$ Wallwork, Durkheim, 49.

${ }^{135}$ Newburn et al., "The Biggest Gang?”, 218.

136 Giddens, Emile Durkheim, 230.

${ }^{137}$ Nick Hopkins et al, "Explaining Effervescence: Investigating the Relationship Between Shared Social Identity and Positive Experience in Crowds," Cognition and Emotion 30, no. 1 (2016): 20.

${ }^{138}$ Cotterrell, Emile Durkheim, 190.

${ }^{139}$ Wallwork, Durkheim, 168.

${ }^{140}$ David Garland, "On the Concept of Moral Panic," Crime and Media Culture 4, no. 1 (2008): 10.

141 Thompson, Emile Durkheim, 1 and 80. 
Dreyfus Affair, ${ }^{142}$ the media influenced society, law, and order during the riots as harsher policing occurred following a public outcry. ${ }^{143}$ The media preps the public for accountability, participating in the criminalisation process. ${ }^{144}$ Politicians described those involved in the riots as being a "vicious immoral minority." 145 The criminalisation of the rioters resulted in a harsh state response. ${ }^{146}$ 24-hour courts were held to distribute sentences alongside pre-emptive policing. ${ }^{147}$ This policing reaction led to the infamous use of stop and search, ${ }^{148}$ indicating that the reaction was multi-layered as it enabled further racial bias in policing. ${ }^{149}$

The description of the riot as acts committed by a "criminal minority" belittled the cry of discontent. ${ }^{150}$ Although explanations for the riots were based on welfare inefficiencies, welfare beneficiaries were demonised by the Prime Minister, who suggested throwing rioters out of their homes. ${ }^{151}$ The responses by the media, police, and politicians did not address inequality, leading to the question of whose solidarity was being constructed. ${ }^{152}$ The delegitimisation and marginalisation of the protestors and rioters contradicts any aim to absolve inequality. This is embedded in the tension founded in contemporary neo-liberal market society, which claims to eradicate class, but actually silences concerns and distributes wealth to the elite few. ${ }^{153}$

A Durkheimian reading of the described event would deem the failure to acknowledge the underlying inequalities behind the anomie-producing behaviour as evidence of a moral crisis expressed through the rise in crime. The state's responses were segmentary, as they did not absolve inequalities. This segmented solidarity included both fiscal inequalities and an

142 Torres, "Durkheim's Concealed," 94.

${ }^{143}$ Hall, Policing the Crisis, 221.

${ }^{144}$ Patrick Williams and Becky Clarke, "Contesting the Single Story: Collective Punishment, Mythmaking and Racialised Criminalisation”, in Media, Crime and Racism, eds. Monish Bhatia, Scott Poynting and Waqas Tufail (London: Palgrave, 2018), 318.

145 Goddard, "BlackLivesMatter", 78.

146 Tim Newburn, "The 2011 England Riots in Recent Historical Perspective," The British Journal of Criminology 55, no. 1 (2015): 57.

${ }^{147}$ Ryan Erfani-Ghettani, "Racism, the Press and Black Deaths in Police Custody in the United Kingdom," in Media, Crime and Racism, eds. Monish Bhatia, Scott Poynting and Waqas Tufail (London: Palgrave, 2018), 269.

148 Newburn et al., "The Biggest Gang?," 216.

${ }^{149}$ Newburn et al., 216.

${ }^{150}$ Erfani-Ghettani, "Racism, the Press and Black Deaths," 265.

${ }^{151}$ Reeves and de Vries, "Does Media Coverage Influence," 285.

152 Reeves and de Vries, "Does Media Coverage Influence," 302.

${ }^{153}$ Elliot-Cooper, "The Struggle That Cannot Be Named," 2450. 
exclusion of Black people within the sacrality of the individual. In an optimistic Durkheimian perspective, this segmentation could be seen as a transitional period. Conversely, it is the sign of a disintegrating solidarity that aligns with "the egotistical nature of Spencer's economics"154 and assures white supremacy. The punishment and crime-based responses to the 2011 riots not only indicate a rejection of Durkheim's ideas to ensure solidarity, but also suggest a continuation of a hierarchical society that evokes moral stagnation. In order to remove the hierarchical solidarity, the reduction of inequalities is central. Race has a unique status in the role of inequalities ${ }^{155}$ which places addressing the racist policing, including the criminalisation process, at the core. The recognition of fiscal inequalities and the inclusion of Blackness within the sacralisation of the individual must be prioritised.

\section{Black Lives Matter}

In contrast to the 2011 Tottenham riots, the recent BLM protests have shifted crime and punishment practices. These global protests have the ability to be "creative epoch,"156 allowing a moral evolution that represents the collective conscience forming a new religion (secular, of course). BLM was chosen for this essay because the police are currently at the centre of the issue.

The BLM protest movement began in 2012 in response to the killing of Trayvon Martin in Florida by George Zimmerman, who was later acquitted. ${ }^{157}$ In 2014, after the death of Michael Brown in Missouri, ${ }^{158}$ the hashtag \#BlackLivesMatter was created to produce a "rallying cry for ALL Black lives striving for Liberation." ${ }^{159}$ The recent tragic events of the murder of George Floyd on the $25^{\text {th }}$ of May 2020 in Minneapolis by police officer Derek Chauvin and his fellow onlooking officers shocked the world. ${ }^{160}$ Floyd's neck was knelt on for nearly nine minutes in response to his potential possession of a counterfeit $\$ 20$. He died on the scene. The

\footnotetext{
${ }^{154}$ Lukes, "Durkheim's Individualism," 20.

155 Allen and Chung, "Your Blues Ain't Like My Blues," 796.

156 Giddens, Emile Durkheim, 231.

${ }^{157}$ Nikita Carney, “All Lives Matter, but so Does Race: Black Lives Matter and the Evolving Role of Social Media," Humanity and Society 40, no. 2 (2016): 181.

${ }^{158}$ Russell-Brown, "Critical Black Protectionism," 401.

${ }^{159}$ Carney, “All Lives Matter,” 181.

${ }^{160}$ Rick Muir, Out Of The Darkness: Policing And The Death Of George Floyd, (London: Police Foundation, 2020).
} 
video of his violent death was widely circulated on social media. This video was reminiscent of Eric Garner's (amongst others') cry of "I can't breathe," as Floyd called out for his mother. BLM symbolises the extent of the loss of Black lives at the hands of the police. ${ }^{161}$ Thousands of people have taken to the streets in "collective action against racial injustice." 162 The majority of the protests consist of peaceful demonstrations, marches, kneeling, and rallies, and contrast starkly to the 2011 Tottenham riots.

Collective effervescence's power to shape society remains true in the case of George Floyd. His death has been the first to result in an officer being charged with murder. ${ }^{163}$ Great social upheaval creates an effervescence that produces revolutionary epochs. ${ }^{164}$ The outcry and demand for accountability will have to be acknowledged if the law is to represent the conscience collective. ${ }^{165}$ Durkheim termed direct action, being that which is publicly visible, "the most forceful means of legitimate communication by the regulated to the regulators." 166 Since the police systematically fail to acknowledge the shift to Black sacredness, BLM is symbolic of those who need to partake in direct action to attain equality and equity. ${ }^{167}$ BLM expands the cult of the individual to include Black people by expressing the "horror" of a killing. ${ }^{168}$ BLM echoes the "linked fate" between the self and the group evident in Black Protectionism. ${ }^{169}$ Durkheim believed an emotional reaction would create social solidarity. ${ }^{170}$ In fact, the disgust, anger, and lamentation surrounding George Floyd's death created international solidarity. Chauvin's blatant disregard for the life of a Black individual was a threat that demanded a collective response. BLM protests embody the piacular ritual on a magnified scale compared to the 2011 riots, representing the "internal cry of the sacred." 171

\footnotetext{
${ }^{161}$ Long, Perpetual Suspects, 219.

162 Hema P. Selvanathan et al, "Whites for Racial Justice: How Contact with Black Americans Predicts Support for Collective Action Among White Americans," Group Processes and Intergroup Relations 21, (no. 6 (2017): 893.

${ }^{163}$ Russell-Brown, "Critical Black Protectionism," 409.

${ }^{164}$ Giddens, Emile Durkheim, 231.

${ }^{165}$ Cotterrell, Emile Durkheim, 176.

${ }^{166}$ Cotterrell, 193-194

167 Cotterrell, 193.

${ }^{168}$ Lukes, "Durkheim's Individualism”, 22.

${ }^{169}$ Russell-Brown, "Critical Black Protectionism,” 369.

${ }^{170}$ Lukes, Emile Durkheim, 163.

${ }^{171}$ Giddens, Emile Durkheim, 234.
} 
As discussed above, mainstream media constructs a powerful collective effervescence ${ }^{172}$ by constructing "good" or "bad victims."173 The partisan reporting in American news polarised attitudes towards BLM. ${ }^{174}$ Reporters focused on brutal confrontations rather than actual events: peaceful rallies and protests. ${ }^{175}$ This connected BLM to radical political ideology, dismissing state-supported systematic racism. ${ }^{176}$ Transformed into a political notion, BLM's demand for equal treatment for Black individuals risks being ignored. The use of social media counteracts such risk by redirecting the attention onto the police's actions. The use of imagery, including that of Black men protecting police officers, ${ }^{177}$ contradicts the mainstream media. Furthermore, distributing images and recordings creates accountability. The media during the 2011 riots shaped public perspectives into a condemning effervescence. In contrast, BLM replaces traditional media with a platform that enables discussion. ${ }^{178}$ Specifically, social media supports a transnational conversation of the oppressive systems ${ }^{179}$ that do not achieve equal opportunity and do not uphold the sacredness of the individual. As such, a solidarity that gives voice to the experience of those often undermined is communicated across the globe. ${ }^{180}$

However, this solidarity requires societal re-construction. Solidarity can be slippery. ${ }^{181}$ It holds colonial notions, requiring the colonised to become "white." 182 Solidarity can become exclusive through only including a proportion of society that fits norms, e.g., those that pass as white. ${ }^{183}$ A form of exclusive solidarity was produced in the responses to the 2011 riots, where those not impacted or involved united in condemnation by removing the voice of those who

172 Thompson, Emile Durkheim, 1 and 80.

${ }^{173}$ Russell-Brown, "Critical Black Protectionism," 403.

${ }^{174}$ Danielle Kilgo and Rachel R. Mourao, "Media Effects and Marginalized Ideas:

Relationships Among Media Consumption and Support for Black Lives Matter," International Journal of Communication 13, (2019): 4291.

175 Kilgo and Mourao, "Media Effects," 4290.

${ }^{176}$ Erfani-Ghettani, "Racism, the Press and Black Deaths," 261.

${ }^{177}$ Gillian Bolsover, "Black Lives Matter Discourse on US Social Media During COVID: Polarised Positions Enacted in a New Event'," Centre for Democratic Engagement (2020): 7.

${ }^{178}$ Carney, “All Lives Matter, but so Does Race," 193.

${ }^{179}$ Carney, 196.

${ }^{180}$ Richard Sparks, "What Are We Going to Do Now? Criminology and Democratic Politics All Over Again," in Criminology and Democratic Politics, eds. Tom Daems and Stefaan Pleysier (London: Routledge, 2021),13.

${ }^{181}$ Roediger, "Making Solidarity Uneasy,” 225.

182 Roediger, 234.

183 Allyson Hobbs, A Chosen Exile: a History of Racial Passing in American Life (London: Harvard University Press, 2016). 
were involved. Social media in BLM has helped re-construct solidarity, avoiding its exclusive potential. More than $65 \%$ of American adults, over two billion people worldwide, use social media every day. ${ }^{184}$ It can "scale up" 185 a movement and mobilise action ${ }^{186}$ to create a new public sphere. ${ }^{187}$ The hashtag removed figurehead leadership, creating globalised protests. ${ }^{188}$ This international response indicates the scale of the impacted collective effervescence. Social media has reformed solidarity, challenging the colonial narrative through the notion of allyship. ${ }^{189}$ Allyship as a form of solidarity resolves issues of Durkheim's solidarity being too homogeneous. ${ }^{190}$ It enables white individuals to become allies to BLM through recognising their white privilege and fighting the reproduction of power dynamics. ${ }^{191}$

The cult of the individual currently conveyed by the police enables continuous violations against Black individuals. BLM indicates a shift away from the "God of the past" to a new inclusive God, ${ }^{192}$ an all-inclusive cult of the individual. The collective conscience contains an essential ability "to renew a system in a process of crisis." 193 The state's decision to prosecute Chauvin aligns with the demands and expectations of the international solidarity. Morality must be "flexible to change in proportion and to the degree which is necessary." 194 The police, who embody values and beliefs, must change accordingly. The solidarity presented by BLM offers an opportunity to address the inequalities of society, but only if communication, deconstruction, and reconstruction occurs.

\footnotetext{
${ }^{184}$ Jonathan M. Cox, "The Source of a Movement: Making the Case for Social Media as an Informational Source Using Black Lives Matter," Ethnic and Racial Studies 40, no.11 (2017): 1847.

${ }^{185}$ Marcia Mundt, Karen Ross and Charla M Burnett, "Scaling Social Movements Through Social Media: The Case of Black Lives Matter," Social Media and Society (2018): 1.

${ }^{186}$ Kilgo and Mourao, "Media Effects," 4289.

${ }^{187}$ Carney, "All Lives Matter, but so Does Race," 184.

${ }^{188}$ Mundt et al., "Scaling Social Movements," 4.

${ }^{189}$ Clark, "White Folks' Work," 520.

${ }^{190}$ McNeill and Dawson, "Social Solidarity," 903.

${ }^{191}$ Clark, "White Folks' Work," 520.

192 Bierstedt, Emile Durkheim, 222.

193 Torres, "Durkheim's Concealed," 110.

${ }^{194}$ Giddens, Emile Durkheim, 112.
} 


\section{The Demand for a Shift}

Durkheim perceives justice not as an ideal, but as a function. ${ }^{195}$ It conveys the relevant societies' solidarity and moral values. ${ }^{196}$ If the current societal order does not enable equality, then it needs to be eradicated and replaced with a new one. ${ }^{197}$ BLM asks allies to challenge the racism within their communities, ${ }^{198}$ interrogating the sometimes subtle ways in which structural racism operates. ${ }^{199}$ White individuals have power in society, holding an important role in advancing efforts towards social change. ${ }^{200}$ There is a need to recognise this power to transfer these benefits to subjugated groups, of which education to promote tolerance, inclusivity, and equality "is one method." 201 If the demand to sacralise the Black individual evident within BLM and as an undercurrent of the 2011 riots is to be met, then allyship must go beyond social media and protests to transformative social change.

Durkheim emphasises the role of schools in socialisation, providing a basis for societal morals. ${ }^{202}$ Since education teaches the solidarity of the given society, it must include the cult of the individual. In 1938, James Cone created a Black Theology in order to reclaim the correlation between Black individuals, Christ, and God. ${ }^{203}$ Although this focuses on Christian theology, it is an example of the need to reframe belief systems in alignment with inclusionary teachings. Copeland took Cone's Black Theology further by framing the eucharist as a ritual to "reclaiming sacred Black bodies," drawing parallels between the cross and the lynching tree. ${ }^{204}$ These reconstructions of Christian theology based on Black experience indicates the need to re-construct exclusionary practices and beliefs. They envisage feasts and ceremonies

195 Herzog, "Durkheim on Social Justice," 117.

${ }^{196}$ Maruna, "Reentry as a Rite," 6.

197 Cotterrell, Emile Durkheim, 183.

${ }^{198}$ Lee et al., "Asians for Black Lives," 412.

${ }^{199}$ Elliot-Cooper, "The Struggle That Cannot be Named," 2459.

${ }^{200}$ Selvanathan, et al., "Whites for Racial Justice," 906.

${ }^{201}$ Clark, "White Folks' Work," 530.

202 Karen Glover, "Identifying Racialized Knowledge Through a Critical Race Studies Lens: Theory and Principles for the Criminology Textbook Realm," Contemporary Justice Review 22, no. 4 (2019): 374.

${ }^{203}$ James H. Cone, A Black Theology of Liberation (New York: Orbis Books, 1968), 73.

${ }^{204}$ M. Shawn Copeland, Enfleshing Freedom: Body, Race and Being (Minneapolis: Fortress Press, 2010), 107-128. 
conducive to social reintegration, ${ }^{205}$ formulating "realistic utopias" to remake and reimagine institutional arrangements. ${ }^{206}$

Democracy is necessary for these ideals to produce a shift, both on a social level and at the state level. ${ }^{207}$ For Durkheim, limitations in state communication are handled by the secondary agencies. ${ }^{208}$ The police represent the direct enactment of communication. However, Durkheim includes an alternative group of communicators: the intellectuals, who ensure the cult of the individual is represented in societal procedures. ${ }^{209}$ This allocation outraged Brunetiere, who responded to the Dreyfus Affair by accusing intellectuals of forming an individualism which leads to anarchy. ${ }^{210}$ Durkheim corrected Brunetiere by explaining the cult of the individual and the role of the intellectual. ${ }^{211} \mathrm{He}$ argued that the role of critiquing society is central to avoid anomie or moral stagnation. ${ }^{212}$

The 2011 Tottenham riots and on-going BLM protest movement question morality held by white privileged individuals. The death of George Floyd and the "racialisation of punishment and crime control" 213 evident in the 2011 riots exposed the "absurdity of the present order." 214 This essay has emphasised that crime control is increasingly under the influence of mass media, which constructs "popular emotion." 215 It is here that this essay points towards the role of the democratic under-labourer ${ }^{216}$ (interchangeable here with the civic criminologist). ${ }^{217}$ To reconfigure the sacred individual, responding to the demand of collective effervescence in order to reduce anomie, Durkheim's need for intellectuals to critique procedural inequalities ${ }^{218}$

205 Richman, Sacred Revolutions, 57.

${ }^{206}$ Ian Loader and Richard Sparks, “Criminology's Public Roles': A Drama in Six Acts," in What is Criminology, eds. Mary Bosworth and Carolyn Hoyle (Oxford: Oxford University Press, 2011), 22.

${ }^{207}$ Cotterrell, Emile Durkheim, 160.

${ }^{208}$ Lukes, Emile Durkheim, 269.

${ }^{209}$ Lukes, "Durkheim's Individualism."

${ }^{210}$ Lukes, "Durkheim's Individualism."

${ }^{211}$ Lukes, "Durkheim's Individualism."

${ }^{212}$ Lehmann, "The Question of Caste," 583.

${ }^{213}$ Sparks, "What are we Going to do Now?," 3.

${ }^{214}$ Lesley McAra, "Can Criminologists Change the World? Critical Reflections on the Politics, Performance and Effects of Criminal Justice," British Journal of Criminology 57, no. 4, (2017): 768.

${ }^{215}$ Loader and Sparks, "Criminology’s Public Roles," 17.

${ }^{216}$ Loader and Sparks, "Criminology's Public Roles,” 20.

217 Sparks, "What are we Going to do Now?," 282.

${ }^{218}$ Lehmann, "The Question of Caste," 583. 
must be implemented. This aligns with Loader and Sparks' democratic under-labourer, who must critique pre-existing norms to create innovative new approaches. ${ }^{219}$ Criminologists must examine their own involvement in forwarding racial discourse. ${ }^{220}$ The colour-blind racism detailed by Bonilla-Silva ${ }^{221}$ enables the silencing of race, even in co-existence of contradictory data. ${ }^{222}$ Criminology's use of race as a variable misunderstands race as a biological phenomenon rather than recognising it as an ideological one. ${ }^{223}$ Glover expresses how this enables the criminalisation of Black individuals, ${ }^{224}$ producing the criminalblackman. ${ }^{225}$ Taking Black Theology as an example, criminology must reconsider approaches to crime and punishment to dismantle racist tendencies. Civic criminologists who create relationships with "communities of interest" 226 could be exemplars of the communication Durkheim stipulates for democracy. This will allow a "deeper democratization" to address predicaments, ${ }^{227}$ recognising voices and "re-legitimising institutions"228 that have lost respect.

Black victim experience can "excavate racist processes." ${ }^{229}$ Interviews with 2011 riot participants by Newburn ${ }^{230}$ were at first dismissed as a vindicatory piece of work produced by mob apologists. ${ }^{231}$ This indicated that work is only praised if it fits elite political agenda, ${ }^{232}$ replicating existing values. There is an urgency for democratic under-labourers to challenge and interrogate current policies and practices. Otherwise, as Durkheim feared, the segmentary society will remain, ${ }^{233}$ and the monstrous subordination Black people still face ${ }^{234}$ will not be reduced. In BLM focused research, regular interaction cross-demographics influences

${ }^{219}$ Loader and Sparks, "Criminology's Public Roles,” 22.

${ }^{220}$ Glover, "Identifying Racialized Knowledge," 371.

${ }^{221}$ Eduardo Bonilla-Silva, Racism Without Racists: Color-blind Racism and the Persistence of Racial Inequality in the United States, 3rd ed. (New York: Rowman and Littlefield Publishers, 2010).

${ }^{222}$ Russell-Brown, "Critical Black Protectionism," 382.

${ }^{223}$ Glover, "Identifying Racialized Knowledge," 373.

${ }^{224}$ Glover, "Identifying Racialized Knowledge." Press, 2009).

${ }^{225}$ Katheryn Russell-Brown, The Color of Crime, 2nd ed. (New York: New York University

${ }^{226}$ Sparks, "What are we Going to do Now?," 10.

${ }^{227}$ Sparks, "What are we Going to do Now?," 15.

${ }^{228}$ Sparks, "What are we Going to do Now?," 15.

${ }^{229}$ Long, Perpetual Suspects, 208.

${ }^{230}$ Newburn et al., "The Biggest Gang?," 209.

${ }^{231}$ Tim Newburn, "Counterblast: Young People and the August 2011 Riots," The Howard Journal 51, no. 3 , (2012): 334.

${ }^{232}$ McAra, "Can Criminologists," 982.

${ }^{233}$ McNeill, and Dawson, "Social Solidarity," 895.

${ }^{234}$ Russell-Brown, "Critical Black Protectionism," 370. 
relations. ${ }^{235}$ There is a positive correlation of peaceful interactions between ethnic groups and participation in BLM protests. ${ }^{236}$ Durkheim indicated that a growth in society that produced regular interaction would enable the recognition of the higher common collective individual. ${ }^{237}$ This knowledge provides pragmatic insights into reconstructing solidarity. The existence of racialised areas ${ }^{238}$ needs to be dismantled if the cult of the individual is to include Black people. The requisite for better community relations between Black communities and the police ${ }^{239}$ should be prioritised in crime control and punishment policies. Loader and Sparks' democratic under-labourer, who thinks of possible futures ${ }^{240}$ offering "alternative ways of thinking about and responding to crime, ${ }^{241}$ should undertake such tasks in response to the exposed racism in institutions.

\section{Concluding Remarks}

The value of Durkheim's ideas to address contemporary problems in crime and punishment policies and practices is significant, as his concepts illuminate embedded inequalities. A neoDurkheimian influenced perspective includes and prioritises racial inequalities.

Through applying Durkheim's concepts, this essay has shown that the 2011 Tottenham riots initially conveyed the problematic exclusion of Black individuals from sacralisation but went on to express the economic disparities present within the current neo-liberal society. The political, media, and police responses to the riots did not address the anomie produced by inequality or the threat to the sacred individual. Rather, the riots were perceived as a crime that offended the norm. Alternatively, BLM's use of social media focuses solely on the exclusionary sacrality enacted by the police. BLM questions the racially disproportionate actions of the police. ${ }^{242}$ A neo-Durkheimian study of the events reveal a collective effervescence that could be determining moments in social development.

\footnotetext{
${ }^{235}$ Selvanathan, et al., "Whites for Racial Justice," 894.

${ }^{236}$ Selvanathan, et al., "Whites for Racial Justice," 895.

237 Giddens, Emile Durkheim, 184.

${ }^{238}$ Elliot-Cooper, "The Struggle that Cannot be Named," 2449.

${ }^{239}$ Long, Perpetual Suspects, 217.

${ }^{240}$ Loader and Sparks, "Criminology's Public Roles," 29.

${ }^{241}$ Loader and Sparks, "Criminology's Public Roles," 22.

${ }^{242}$ Russell-Brown, "Critical Black Protectionism," 379.
} 
Although this essay does not provide solutions to the evidently overwhelming problem of institutionalised racism, it demonstrates the importance of Durkheim's ideas when considering societal solidarity. It has illuminated the power of the police in communicating morality, implying that the police are a good starting point in reconstructing solidarity. "De-fund the police" 243 could be interpreted as an opportunity to address institutional racism by building community relations, thereby embodying the collective effervescence created by these events, of which the ultimate expression is treating all individuals as sacred, ${ }^{244}$ regardless of race.

Durkheim's emphasis on democracy with intellectuals informing legislators of social needs ${ }^{245}$ is also of value. This essay assigned the role of Durkheim's intellectuals to the democratic under-labourer. The criminologist must align crime and punishment policies to the core values of society, expanding the cult of the individual to be inclusive of Black people. The criminologist must remember the radical notion of critiquing social structures to better society's cohesion. ${ }^{246}$ Failure to do so will result in anomie sustaining the criminogenic hierarchical state. ${ }^{247}$ Controversy must not be cowered from. This is how moral stagnation can be avoided and crime and punishment policies attuned to the undercurrents of the riots and the demands of BLM can be produced.

\section{Bibliography}

Allen, Walter and Angie Chung. "Your Blues Ain't Like My Blues: Race Ethnicity and Social Inequality in America.” Contemporary Sociology 29, no.6 (2000): 796-805. https://doi.org/10.2307/2654087.

Besnard, Philippe. “Anomie and Fatalism in Durkheim's Theory of Regulation” In Emile Durkheim: Sociologist and Moralist, edited by Stephen Turner, 163-183. London: Taylor \& Francis Group, 1993.

Bierstedt, Robert. Emile Durkheim. London: Weidenfeld and Nicolson, 1966.

\footnotetext{
${ }^{243}$ Sparks, "What are we Going to do Now?," 8.

${ }^{244}$ Lukes, "Durkheim's Individualism," 14.

${ }^{245}$ Cotterrell, Emile Durkheim, 176.

246 Wallwork, Durkheim, 171.

${ }^{247}$ Messner et al., "Institutions, Anomie and Violent Crime," 170.
} 
Bolsover, Gillian. "Black Lives Matter Discourse on US Social Media During COVID: Polarised Positions Enacted in a New Event." Centre for Democratic Engagement, (2020): 1-10. https://arxiv.org/pdf/2009.03619.pdf.

Bonilla-Silva, Eduardo. Racism without Racists: Color-blind Racism and the Persistence of Racial Inequality in the United States. $3^{\text {rd }}$ ed. New York: Rowman and Littlefield Publishers, 2010.

Burkhardt, Brett C. and Brian T. Connor. "Durkheim, Punishment and Prison Privatisation." Social Currents 3, no. 1 (2016): 84-99. https://doi.org /10.1177/2329496515604641.

Carney, Nikita. "All Lives Matter, but so Does Race: Black Lives Matter and the Evolving Role of Social Media." Humanity and Society 40, no. 2 (2016): 180-199. https://doi.org/10.1177\%2F0160597616643868.

Clark, Meredith D. "White Folks' Work: Digital Allyship Praxis in the \#BlackLivesMatter Movement." Social Movement Studies 18, no. 5 (2019): 519-534. https://doi.org/10.1080/14742837.2019.1603104.

Cone, James H. A Black Theology of Liberation. New York: Orbis Books, 1968.

Copeland, M. Shawn. Enfleshing Freedom: Body, Race and Being. Minneapolis: Fortress Press, 2010.

Cotterrell, Roger. Emile Durkheim: Law in a Moral Domain. Edinburgh: Edinburgh University Press, 1999.

Cotterrell, Roger. “Justice, Dignity, Torture, Headscarves: Can Durkheim's Sociology Clarify Legal Values." Social and Legal Studies 20, no. 1 (2011): 3-20. https://doi.org/10.1177/0964663910378433.

Cox, Jonathan M. "The Source of a Movement: Making the Case for Social Media as an Informational Source Using Black Lives Matter." Ethnic and Racial Studies 40, no. 11 (2017): 1847-1854. https://doi.org/10.1080/01419870.2017.1334935.

DiCristina, Bruce. "Durkheim's Theory of Anomie and Crime: A Clarification and Elaboration." Australia and New Zealand Journal of Criminology 49, no. 3 (2016): 311-331. https://doi.org/10.1177/0004865815585391.

Durkheim, Emile. The Elementary Forms of Religious Life: A Study in Religious Sociology. Translated by Joseph Swain. London: Allen and Unwin, 1912. 
Durkheim, Emile. The Division of Labor in Society. Translated by George Simpson. New York: Macmillan, 1933.

Durkheim, Emile. Sociology and Philosophy. Translated by David F. Pocock. London: Cohen and West, 1953.

Elliott-Cooper, Adam. "The Struggle that Cannot be Named: Violence, Space and the Rearticulation of Anti-racism in post-Duggan Britain." Ethnic and Racial Studies 41, no. 14 (2018): 2445-2463. https://doi.org/10.1080/01419870.2017.1367020.

Erfani-Ghettani, Ryan. "Racism, the Press and Black Deaths in Police Custody in the United Kingdom” In Media, Crime and Racism, edited by Monish Bhatia, Scott Poynting and Waqas Tufail, 255-275. London: Palgrave, 2018.

Filloux, Jean-Claude. "Inequalities and Social Stratification in Durkheim's Sociology” In Emile Durkheim: Sociologist and Moralist, edited by Stephen P. Turner, 205-221. London: Taylor and Francis Group, 1993.

Garland, David. "Frameworks of Inquiry in the Sociology of Punishment." The British Journal of Sociology 41, no. 1 (1990): 1-15. https://doi.org/10.2307/591014.

Garland, David. "Concepts of Culture in the Sociology of Punishment." Theoretical Criminology 10, no. 4 (2006): 419-447. https://doi.org/10.1177/1362480606068873.

Garland, David. "On the Concept of Moral Panic." Crime and Media Culture 4, no. 1 (2008): 9-30. https://doi.org/10.1177/1741659007087270.

Giddens, Anthony, ed. Emile Durkheim: Selected Writings. Cambridge: Cambridge University Press, 1972.

Glover, Karen S. "Identifying Racialized Knowledge Through a Critical Race Studies Lens: Theory and Principles for the Criminology Textbook Realm." Contemporary Justice Review 22, no. 4 (2019): 371-388. https://doi.org/10.1080/10282580.2019.1672542.

Goddard, Lynette. "BlackLivesMatter: Remembering Mark Duggan and David Oluwale in Contemporary British Plays." Journal of Contemporary Drama in English 6, no. 1 (2018): 69-86. https://doi.org/10.1515/jcde-2018-0012.

Grint, Keith and Darren Nixon. The Sociology of Work. $4^{\text {th }}$ ed. Cambridge: Polity Press, 2015.

Hall, Stuart. Policing the Crisis: Mugging, the State and Law and Order. New York: Macmillan Publishers, 1978. 
Herzog, Lisa. "Durkheim on Social Justice: The Argument from 'Organic Solidarity'." American Political Science Review 112, no. 1 (2018): 112-124. https://doi.org/10.1017/S000305541700048X.

Hobbs, Allyson. A Chosen Exile: A History of Racial Passing in American Life. London: Harvard University Press, 2016.

Hopkins, Nick, Stephen D. Reicher, Sammyh S. Khan, Shruti Tewari, Narayanan Srinivasan and Clifford Stevenson. "Explaining Effervescence: Investigating the Relationship Between Shared Social Identity and Positive Experience in Crowds." Cognition and Emotion 30, no. 1 (2016): 20-32. https://doi.org/10.1080/02699931.2015.1015969.

Jackson, Jonathan and Jason Sunshine. "Public Confidence in Policing: A Neo-Durkheimian Perspective.” The British Journal of Criminology 47, no. 2 (2007): 214-233. https://doi.org/10.1093/bjc/azl031.

Kapoor, Nisha and Kasia Narkowicz. "Characterising Citizenship: Race, Criminalisation and the Extension of Internal Borders." Sociology 53, no. 4 (2019): 652-670. https://doi.org/10.1177/0038038518820250.

Kilgo, Danielle and Rachel R. Mourao. "Media Effects and Marginalized Ideas: Relationships Among Media Consumption and Support for Black Lives Matter." International Journal of Communication 13 (2019): 4287-4305.

Lee, Stacy J., Choua P. Xiong, Linda M. Pheng and Mai Neng Vang. “Asians for Black Lives, Not Asians for Asians: Building Southeast Asian American and Black Solidarity." Anthropology and Education 51, no. 4 (2020): 405-421. https://doi.org/10.1111/aeq.12354.

Lehmann, Jennifer. “The Question of Caste in Modern Society: Durkheim's Contradictory Theories of Race, Class and Sex." American Sociological Review 60, no. 4 (1995): 566-585.

Loader, Ian and Richard Sparks. "Criminology's Public Roles: A Drama in Six Acts” In What is Criminology, edited by Mary Bosworth and Carolyn Hoyle, 17-34. Oxford: Oxford University Press, 2011.

Long, Lisa J. Perpetual Suspects. London: Palgrave Studies, 2018.

Lukes, Steven. “Durkheim's Individualism and the Intellectuals.” Political Studies 17, no.1 (1969): 14-30. https://doi.org/10.1111/j.1467-9248.1969.tb00622.x

Lukes, Steven. Emile Durkheim. Middlesex: Penguin Books Ltd, 1973. 
Mannion, Elgin. "Autonomy, Race and State Reproduction of Status: Durkheim and Weber on Education and Immigration.” Critical Sociology 42, no. 4-5 (2016): 699-714. https://doi.org/10.1177/0896920514544042.

Maruna, Shadd. "Reentry as a Rite of Passage." Punishment and Society 13, no. 1 (2011): 328. https://doi.org/10.1177/1462474510385641.

McAra, Lesley. "Can Criminologists Change the World? Critical Reflections on the Politics, Performance and Effects of Criminal Justice." British Journal of Criminology 57, no. 4 (2017): 767-788. https://doi.org/10.1093/bjc/azw015.

McNeill, Fergus and Matt Dowson. "Social Solidarity, Penal Evolution and Probation." The British Journal of Criminology 54, no. 5 (2014): 892-907. https://doi.org/10.1093/bjc/azu042.

Messner, Steven F., Helmut Thome and Richard Rosenfeld. "Institutions, Anomie and Violent Crime: Clarifying and Elaborating Institutional-Anomie Theory." International Journal of Conflict and Violence 2, no. 2 (2008): 163-181. https://doi.org/10.4119/ijcv-2763.

Morrison, Ken. Marx, Durkheim, Weber. London: SAGE Publications, 1998.

Muir, Rick "Out of the Darkness: Policing and the Death of George Floyd." London: Police Foundation. 2020. Accessed 10.12.20. http://www.policefoundation.org.uk/2020/06/policing-and-the-death-of-george-floyd/.

Mundt, Marcia, Karen Ross and Charla Burnett. "Scaling Social Movements Through Social Media: The Case of Black Lives Matter." Social Media and Society, (2018): 1-14. https://doi.org/10.1177\%2F2056305118807911.

Newburn, Tim. "Counterblast: Young People and the August 2011 Riots." The Howard Journal 51, no. 3 (2012): 331-335. https://doi.org/10.1111/j.1468-2311.2012.00719.x

Newburn, Tim. "The 2011 England Riots in Recent Historical Perspective." The British Journal of Criminology 55, no. 1 (2015): 39-64. https://doi.org/10.1093/bjc/azu074.

Newburn, Tim, Rebekah Diski, Kerris Cooper, Rachel Deacon, Alex Burch and Maggie Grant. "The Biggest Gang? Police and People in the 2011 England Riots." Policing and Society 28, no. 2 (2018): 205-222. https://doi.org/10.1080/10439463.2016.1165220.

Reeves, Aaron and Robert de Vries. "Does Media Coverage Influence Public Attitudes Towards Welfare Recipients? The Impact of the 2011 English Riots." The British 
Journal of Sociology 67, no. 2 (2016): 281-306. https://doi.org/10.1111/14684446.12191.

Richman, Michele H. Sacred Revolutions: Durkheim and the Collège de Sociologie. Minnesota: University of Minnesota Press, 2002.

Roediger, David. "Making Solidarity Uneasy: Cautions on a Keyword from BLM to the Past." American Quarterly 68, no. 2 (2016): 223-248. https://doi.org/10.1353/aq.2016.0033.

Russell-Brown, Katheryn. The Color of Crime. $2^{\text {nd }}$ ed. New York: New York University Press, 2009.

Russell-Brown, Katheryn. "Critical Black Protectionism, Black Lives Matter, and Social Media: Building a Bridge to Social Justice." Howard Law Journal 60 (2017): 367412.

Selvanathan, Hema Preya, Pirathat Techakesari, Linda R. Tropp and Fiona Kate Barlow. "Whites for Racial Justice: How Contact with Black Americans Predicts Support for Collective Action Among White Americans." Group Processes and Intergroup Relations 21, no. 6 (2017): 893-912. https://doi.org/10.1177/1368430217690908.

Sparks, Richard. "What are we Going to do Now? Criminology and Democratic Politics All Over Again." In Criminology and Democratic Politics, edited by Tom Daems and Stefaan Pleysier, 275-288. London: Routledge, 2021.

Thompson, Kenneth. Emile Durkheim. Chichester: Ellis Horwood Ltd, 1982.

Torres, Eduardo C. "Durkheim's Concealed Sociology of the Crowd." Durkheimian Studies 20 (2014): 89-114. https://doi.org/ 10.3167/ds.2014.200105.

Wacquant, Loic. "From Slavery to Mass Incarceration.” New Left Review 13 (2002): 41-60.

Waddington, David. "The Law of Moments: Understanding the Flashpoint that Ignited the Riots." Criminal Justice Matters 87, no. 1 (2012): 6-7. https://doi.org/10.1080/09627251.2012.670993.

Wallwork, Ernest. Durkheim: Morality and Milieu. Cambridge: Harvard University Press, 1972.

Weiss, Raquel. "From Ideas to Ideals: Effervescence as the Key to Understanding Morality." Durkheimian Studies 18, no. 1 (2012): 81-97. https://doi.org/10.3167/ds.2012.180106. 
Williams, Patrick and Becky Clarke. "Contesting the Single Story: Collective Punishment, Myth-making and Racialised Criminalisation" In Media, Crime and Racism, edited by Monish Bhatia, Scott Poynting and Waqas Tufail, 317-336. London: Palgrave, 2018. 